\title{
Qualitative and quantitative evaluation of the ciliated protozoa in the middle northern coast of Egypt
}

\author{
Mansour A. Galal \\ Zoology Department, Faculty of Science, Menoufyia University
}

\begin{abstract}
Protozoa play an important role in the different aquatic food webs. The main objective of this study is to identify the most abundant types of the ciliated protozoa at sampling stations extending along the middle northern coast of about $135 \mathrm{Km}$ in Egypt . Three different classes of ciliated protozoa were detected at three sampling stations. These classes comprised seven subclasses which include 13 different orders. These orders were represented by more than 79 ciliate species. The numbers of the ciliate species at western Alexandria sampling station were 78, those of El-Hamaam achieved 70 and that of Sedi-A. Rhman reached 66 species only. The highest ciliate numerical densities were detected within class kinetofragminophora, followed by Oligohyminophora and then Polyhyminophora in the latter two stations, while those of Alexandria proved that Oligohymenophora exceeds the other two classes.

Data of the present study illustrated that the level of $\mathrm{p}^{\mathrm{H}}$ is slightly alkaline (7.6-7.93), salinity is $8.2-12.3 \%$, water temperature is $11.3-27.4{ }^{\circ} \mathrm{C}$, turbidity is $21.5-50.4 \mathrm{NTU}, \mathrm{POC}$ is $0.85-1.4 \mathrm{mg} / \mathrm{L}$ and dissolved oxygen is $6.3-7.8 \mathrm{mg} / \mathrm{L}$. On the other hand, nutrient concentrations in that region of the Mediterranean sea are 2.9-7.4 ug/L for Ch-a and 0.21 $0.61,0.60-0.92,0.019-0.078 \mathrm{mg} / \mathrm{l}$ for silicate, total nitrates and total phosphates, respectively. Accordingly, it appears that these stations are more or less eutrophic particularly those of Alexandria followed by El-Hamaam and then Sedi-A.Rhman. Simultaneously, the nutrient concentrations of the present investigation are mostly higher as compared with those of the other studies. Comparing the numerical densities of both aquatic and bottom ciliated protozoan organisms belonging to the different classes at those three sampling stations proved that the ciliates inhabiting the sand grains of the latter are much higher than those of the former one by three to six times.
\end{abstract}

Key words: Ciliates, Mediterranean sea, Northern coast.

\section{INTRODUCTION}

Protozoa are important biotic components in the aquatic ecosystem, particularly ciliates, which act as predators of bacteria and other micro-organisms beside some rotifers. In addition, they provide nutrition for organisms at higher trophic levels (Kneitel \& Chase, 2004 and Dopheide et al., 2009), increase mineralization and make nutrients more available to other organisms (Vickerman, 1992). Protozoa play also a crucial role in the food chains as bio-monitors and/or indicators of water quality (Charubhun and Charubhun, 2000). Few protozoan data have been collected in several zooplankton studies along the Egyptian Mediterranean Coast (Abdel-Aziz, 2004 , Abdel-Aziz \& Aboul-Ezz, 2003; Anon, 2007). Marine protozoa comprise certain groups such as radiolarians and foraminiferans that have biological significance in sediments only. Other marine sarcodines can not be identified due to their body fragility and their relatively low quantitative and qualitative values. Most of the flagellates are difficult to be examined microscopically according to their very minute size. On the other hand, most of marine free-living ciliates are widely distributed, dominate in both species numbers and numerical densities. In addition, protozoan organisms play a vital role 


\section{Mansour A. Galal}

in the microbial food web (Lee \& Choi, 2000) beside their high tolerance against extreme environmental conditions such as heavy metals and sewage pollution (Forge et al., 1993).

Diversity and structure of ciliate communities in Gabes' Gulf in Tunisia were investigated at near-shore stations along $237 \mathrm{Km}$. where high ciliate species richness was recorded ( Elloump et al., 2015).

Ciliated protozoa as microbivores appear to stimulate the rates of carbon and nitrogen cycling (Fenchel, 1987; Finlay et al., 2004). Great numbers of ciliates feed mostly on bacteria and not on dissolved organic material and compete with other ciliates and rotifers for different bacteria. Damietta coast as a part of the Egyptian Mediterranean coast is considered as a polluted area due to an exaggerated human activity. The environmental parameters of previous investigations showed low salinity, mild anoxic conditions, enough nutrient levels and quite phytoplankton growth. A total of 69 protozoan species were identified and their annual numerical densities varied between $8.2 \times 10^{3}$ and $51.4 \times 10^{3}$ cells $\mathrm{m}^{-3}$ and the highest values were obtained during Spring (Dorgham et al., 2013).

The population densities of filter-feeding ciliates at three marine protectorates (Ras Mohammed, Nabq and Abu Galoum) in Al-Aqaba Gulf at the northern Red Sea, were evaluated by El-Serehy et al. (2012). The ciliate abundance in these sampling sites were found to vary according to an annual cycle where the highest ciliate numerical densities $\left(2.5 \times 10^{4}\right.$ cells/ L) was obtained on spring and the lowest values $\left(0.2 \times 10^{4}\right.$ cells/ $\left.\mathrm{L}\right)$ was detected during summer.

\section{MATERIALS AND METHODS}

The studying area extends along the Middle Northern Mediterranean coast of Egypt for about $135 \mathrm{KM}$. It includes three sampling stations; western coast of Alexandria city, ElHamaam and Sedi A. Rahman towns as could be seen in Figure (1).

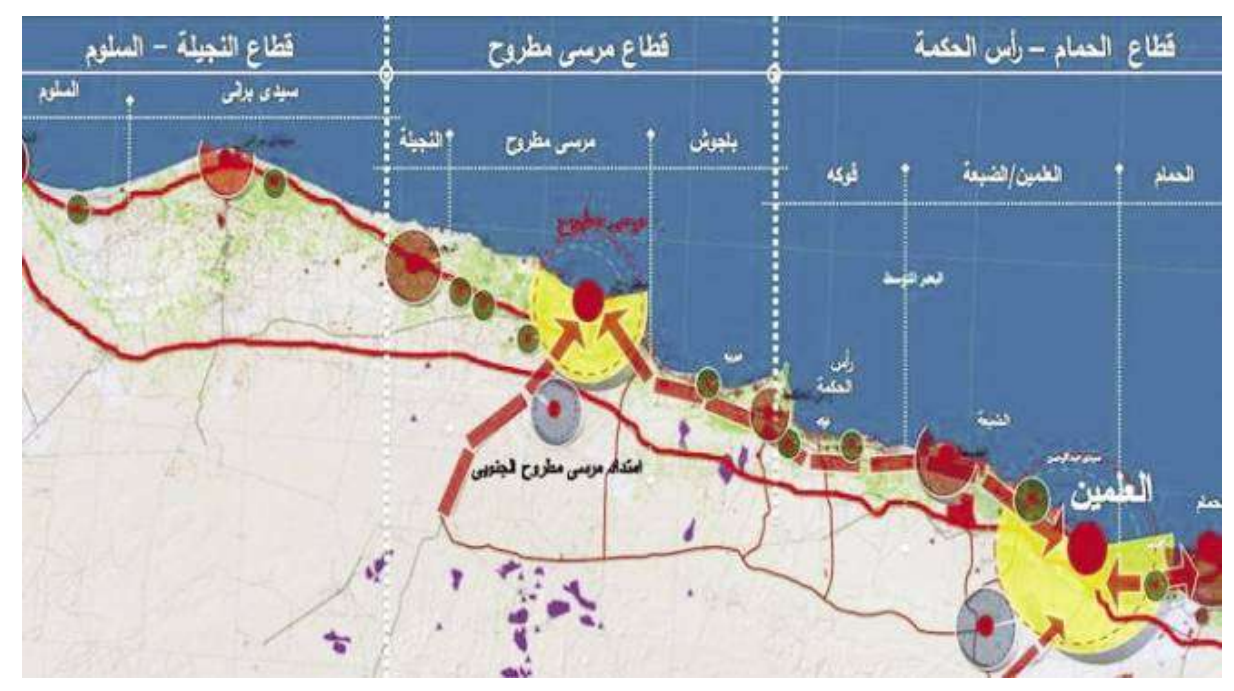

Fig. (1). Map of sampling sites at the Middle Northern Mediterranean coast of Egypt ; western coast of Alexandria city, El-Hamaam and Sedi A. Rahman towns ( Source : Google Earth). 


\section{Qualitative and quantitative evaluation of the ciliated protozoa in the middle northern coast of Egypt}

Sampling was carried out during March (1, 8, 15, 22, 29) and April (5, 12, 19, 26), 2014. A total of 27 sediment samples and another 27 aquatic ones were collected from those sampling stations. Sand samples were picked up early morning at about $50 \mathrm{~cm}$ water depth by pressing a rectangular brass corer of $10 \mathrm{~cm}$ length and $1 \mathrm{~cm}^{2}$ cross area into the sandy bottom to collect sand and its protozoa, Sand of each corer was placed in a glass funnel coated internally with a double- muslin layer in order to extract protozoa and to prevent sand grains to pass. Each funnel was placed over a 100 ml- cylindrical Perspex chamber (Fig. 2).

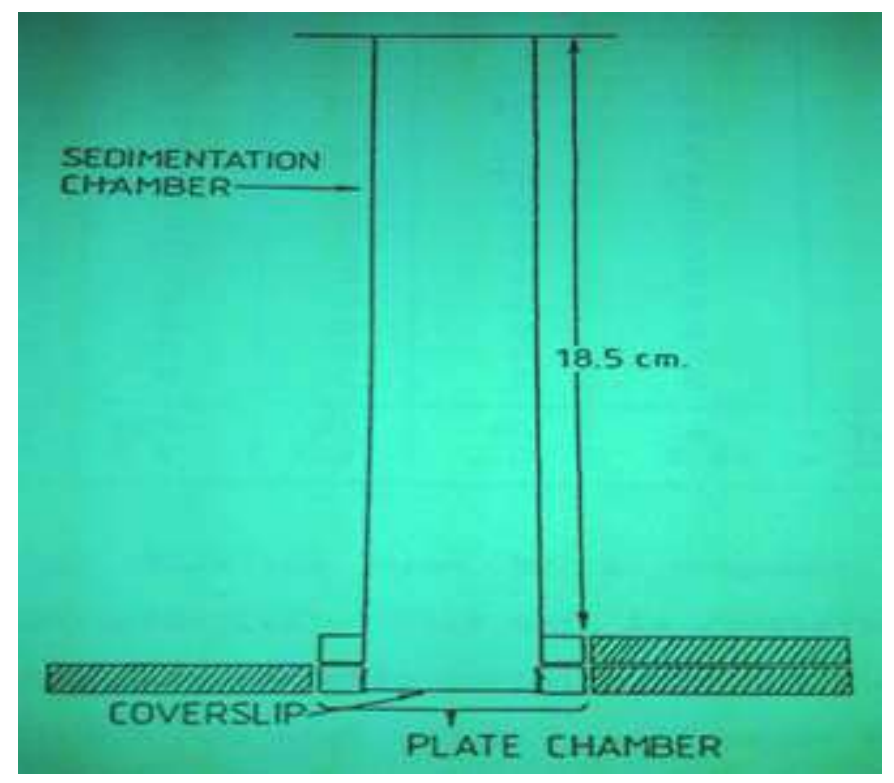

Fig. (2). The Sedimentation Chamber for ciliated protozoa

This was followed by pipetting sea water above the sand samples to drive the protozoan organisms away (Galal,1989). On the other hand, sea water was collected using a perspex sampler ( of one-liter volume) at about $30 \mathrm{~cm}$ below water surface at the same sampling sites. Enumeration, identification and classification of these protozoans were carried out via Corliss (1979) and Levin et al. (1980). Microscopical examination was carried out by the help of Carl- Zeiss Jena transmitted- light inverted microscope. It was found helpful to slow down the rapid movements of many of these ciliated organisms by adding few drops of methyl cellulose solution (15 gm in $85 \mathrm{ml}$ water) to the preparation inside the basal part of the sedimentation chamber. Most of the physico-chemical parameters of water such as salinity, POC, turbidity, dissolved oxygen, $\mathrm{pH}$, Ch-a, silicates, total phosphate and nitrate salts were measured depending on APHA (2005).

\section{RESULTS}

The microscopical examination revealed that different organisms belonging to many taxa were present in the collected samples from the three sampling stations at the middle part of the egyptian northern coast. These organisms include rotifers, worms (nematodes and polychaetes), crustacean larvae and tremendous types and numbers of different protozoan organisms. Protozoa were proved to be the most abundant group among other organisms. They are represented by two phyla; Sarcomstigophora and Ciliophora. 


\section{Mansour A. Galal}

Ciliated protozoan organisms were proved to be higher than both sarcodines and mastigophoreans from diversity and numerical density point of view. Subphylum Sarcodina is represented, in the present study, by Rhizopodea (naked amoebae) such as Arcella discoids, A. vulgaris, Amoeba proteus \& A. striata and Actinopodea (testate amoebae) comprising Actinosphaerium sp., Centropyxis sp., while Mastigophora comprises Phytomastigophorea (Oicomonas, Chilomonas, Cryptomonas, Euglena, Peranema and Heteronema species) and Zoomastigophorea (Monosiga sp and Bodo sp. ). On the other hand, phylum Ciliophora is represented totally in those three sampling stations by more than 79 ciliate species/genera belonging to 13 orders of three main classes, namely Kinetofragminophora, Oligohymenophora and Polyhymenophora . It was found that the number of the ciliate species (species richness) at Alexandria sampling station is 78, that of El-Hamaam is 70 and that of Sedi-A. Rhman is 66 individuals of this protozoan class (Ciliophora).

Data in Table (1) indicated that Alexandria sampling station has higher numerical densities of ciliated protozoa than those of El-Hmaam then Sedi- A. Rhman. The highest ciliate numerical densities were found in class kinetofragminophora followed by those of Oligohyminophora and then those of Polyhyminophorea at the latter two sampling stations. At Alexandria station those of Oligohymenophora exceeds those of the other two classes (Kinetofragminophora and Polyhyminophora). Simultaneously, class kinetofragminophora exhibited 40 different genus/species ciliate organisms whose numerical densities are 1680, 1130 \& 984/L at Alexandria, El-Hamaam and Sedi-A. Rahman, while Oligohymenophora was represented by 23 types of various protozoan species and the densities are $2028,813 \& 688 / \mathrm{L}$, respectively.

Table (1). Numerical densities $\left(n^{0} / L\right)$ of ciliated Protozoa belonging to different classes in the middle northern coast of Egypt.

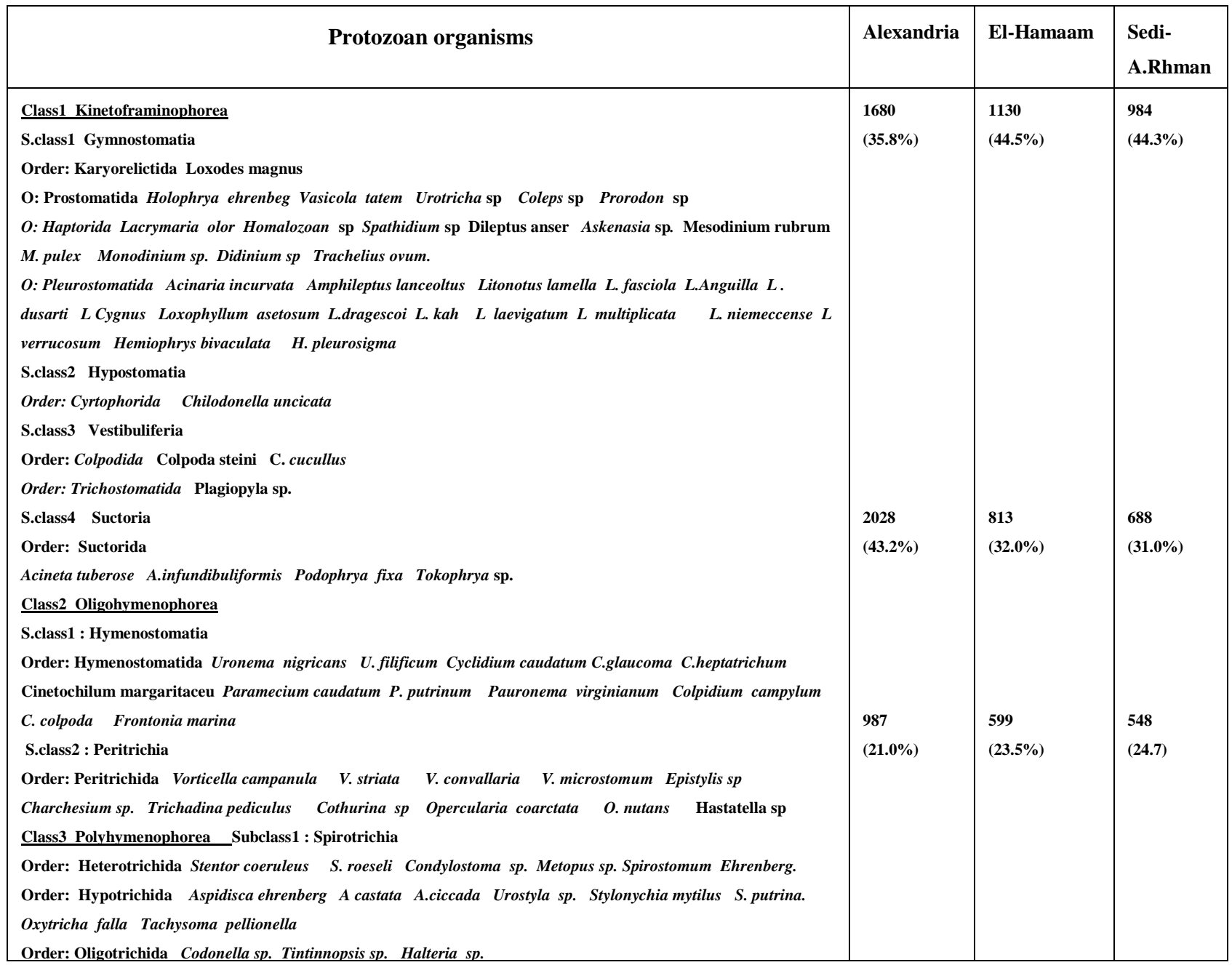




\section{Qualitative and quantitative evaluation of the ciliated protozoa in the middle northern coast of Egypt}

On the other hand, Polyhymenophora was illustrated by 16 ciliated protozoan genus/species whose densities are 987, $599 \& 548 / \mathrm{L}$. At the same time, the percentages of the three ciliate classes at both El-Hamaam and Sedi-A.Rhman are more or less similar, $44.5 \%$ and $44.3 \%$, for Kinetofragminophora, $32.0 \%$ and $31.0 \%$ for Oligohymenophora, $23.5 \%$ and $24.7 \%$ for Polyhymenophora, while those of Alexandria sampling station were lesser than those of the previously mentioned stations apart from that of class Oligohymenophora.

Regarding the ciliate numerical densities and their percentages belonging to the different orders, it was proved that the ciliate orders having the highest numerical densities are restricted to Alexandria station followed by those of Sedi A. Rhman. On the contrary, the highest percentages of these orders are belonging to Sedi A. Rhman followed by those of western Alexandria and at El-Hamaam as could be seen in Table (2).

Table (2). Numerical densities $\left(\mathrm{n}^{0} / \mathrm{L}\right)$ of ciliates belonging to different orders and their percentages at various sampling stations in the middle northern coast of Egypt.

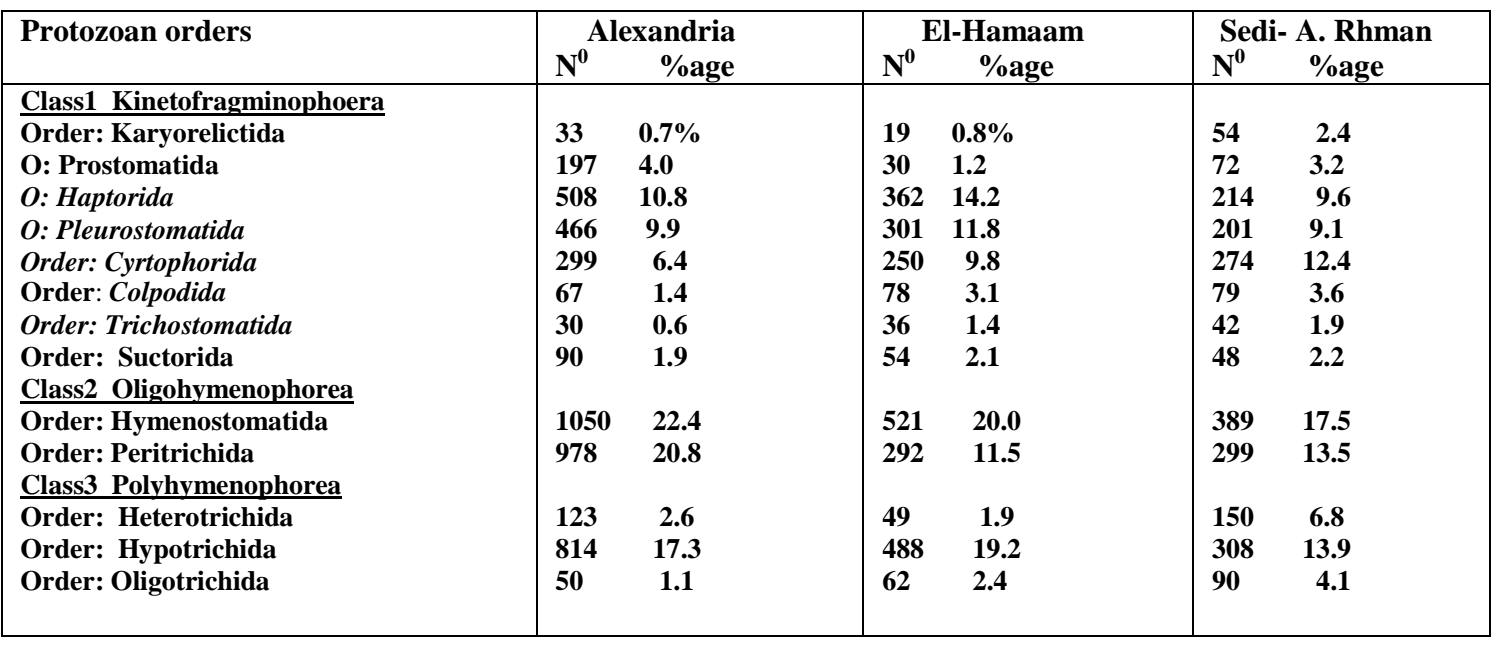

Comparing the numerical densities of both aquatic and sediment ciliated protozoan organisms belonging to the previously mentioned classes at the various sampling stations indicated that the sediment samples having higher ciliate numerical densities than those of the aquatic ones by more or less three to six times as could be predicted from Table (3).

\begin{tabular}{|l|ccc|cc|cc|}
\hline Sampling station & \multicolumn{2}{|c|}{ Alexandria } & \multicolumn{2}{|c|}{ El-Hammam } & \multicolumn{2}{|c|}{ Sedi.A. Rhman } \\
& S & A & S & A & S \\
\hline Class: Kinetofragminophorea & $\mathbf{1 6 8 0}$ & $\mathbf{3 8 9}$ & $\mathbf{1 1 3 0}$ & $\mathbf{2 8 2}$ & $\mathbf{9 8 4}$ & $\mathbf{1 8 4}$ \\
Class: Oligohyminophorea & $\mathbf{2 0 2 8}$ & $\mathbf{5 1 2}$ & $\mathbf{8 1 3}$ & $\mathbf{1 7 8}$ & $\mathbf{6 8 8}$ & $\mathbf{1 4 8}$ \\
Class: Polyhyminophorea & $\mathbf{9 8 7}$ & $\mathbf{3 6 1}$ & $\mathbf{5 9 9}$ & $\mathbf{1 2 6}$ & $\mathbf{5 4}$ & $\mathbf{1 1 4}$ \\
\hline \multicolumn{1}{|c|}{ Total } & $\mathbf{4 6 9 5}$ & $\mathbf{1 2 6 2}$ & $\mathbf{2 5 4 2}$ & $\mathbf{5 8 6}$ & $\mathbf{2 2 2 0}$ & $\mathbf{4 4 6}$ \\
\hline
\end{tabular}

Table (3). Aquatic (A) and sediment (S) numerical ciliate densities at various sampling stations in the middle northern coast of Egypt.

The present study illustrated that the values of $\mathrm{p}^{\mathrm{H}}$ are slightly alkaline (7.6-7.93), the salinity is more or less $32-39 \%$, water temperature is $11.3-27.4{ }^{\circ} \mathrm{C}$, turbidity is $21.5-50.4$ NTU and dissolved oxygen is 6.3-7.7 mg/L, while those of particulate organic carbon (POC) ranged between 0.85 and $1.4 \mathrm{mg} / \mathrm{l}$. On the other hand, nutrient concentrations along that 


\section{Mansour A. Galal}

region of the Mediterranean sea for Ch-a is 2.9-7.4 ug/L, while those of silicate, total nitrates and total phosphates are $0.021-0.061,0.060-00.92,0.019-0.078 \mathrm{mg} / \mathrm{l}$ respectively (Table 4). Simultaneously, the influence of certain physico-chemical parameters on the numerical densities of both aquatic and sediment ciliated protozoa was examined statistically to detect the importance of these factors on the distribution and the abundance of these unicellular organisms.

Table (4). Values of certain environmental parameters at three sampling stations in the middle northern coast of Egypt.

\begin{tabular}{|c|c|c|c|}
\hline Stations & Alexandria & El-Hamaam & Sedi-A.ERhman \\
\hline Temperature $\left[{ }^{\circ} \mathbf{C}\right]$ & $11.3-25$ & $10.5-26$ & $11.8-27.4$ \\
\hline Salinity (\%o) & 32.5 & 35.9 & 39.1 \\
\hline Turbidity (NTU) & 50.4 & 31.0 & 14.9 \\
\hline & 7.6 & 7.81 & 7.93 \\
\hline Dis. Ox. (mg/L) & 6.3 & 7.4 & 7.7 \\
\hline POC $\quad(\mathrm{mg} / \mathrm{L})$ & 1.4 & 1.1 & 0.85 \\
\hline Total $\mathrm{NO}_{3}(\mathrm{mg} / \mathrm{l})$ & 0.096 & 0.072 & 0.060 \\
\hline Total $\mathrm{PO}_{4}(\mathrm{mg} / \mathrm{l})$ & 0.078 & 0.034 & 0.019 \\
\hline Ch-a (ug/l) & 2.9 & 3.6 & 4.7 \\
\hline Silicate (mg/l) & 0.021 & 0.049 & 0.061 \\
\hline
\end{tabular}

\section{DISCUSSION}

In aquatic environments, ciliated protozoan assemblages are important components of the microplankton fauna and are considered primary mediators of energy transfer from pico- and nanoplankton production to higher trophic levels in the functioning microbial loop (Dolan and Coats 1990; Sime-Ngando et al. 1995; Jiang et al,. 2013). It is becoming increasingly recognized that there are several advantages in using ciliated protozoa for the assessment of water quality. As a result of their short life cycles and semipermeable external membranes, they may react more rapidly to the environmental changes than many other eukaryotic organisms. Furthermore, many forms can inhabit environments that are unsuitable to metazoan organisms (Cairns et al., 1972; Franco et al., 1998; Corliss 2002; Madoni and Braghiroli 2007; Jiang et al., 2007).

Parallel to the data obtained by Dorgham et al. (2013), human activities along a coastal region have caused drastic changes in the environment, expressed by a salinity decrease, frequent low and slightly moderate oxygenated conditions and elevated nutrient levels. These changes are reflected in the structure and abundance of the protozoan community in the studying area. From the nutrient concentration point of view, the present sampling stations could be classified as eutrophic with particular reference to those of the former one (west Alexandria station) which is more or less similar to those obtained by Vucak \& Stirn ( 1982), Ignatiades et al. (1992) and Marchetti (1984).

On the other hand, the importance of functional groups of ciliates from marine ecosystems has not been well recognized, especially with respect to the potential capability in the assessment of water quality (Jiang et al., 2013). Jiang et al. (2011) revealed that spatiotemporal patterns of ciliate communities are significantly correlated with environmental conditions and that some dominant species are significantly correlated with concentrations of nutrients. Thus, it is possible to conclude that some ciliate assemblages, as functional groups with specific role in communities, could respond predictably to different environmental conditions. 


\section{Qualitative and quantitative evaluation of the ciliated protozoa in the middle northern coast of Egypt}

According to Balkis (2004), Bel Hassen et al.(2008), Drira et al.(2010) and Hannachi et al. (2009), the quantitative dominance of oligotrich ciliates was found to be related to the oligotrophic status of the studying area at Gulf of Gabes. Simultaneously, it was proved that the quantitative dominance of certain tintinnid ciliated protozoan organisms was related to the pollution level at the same gulf in Tunisea (Drira et al., 2008; Hannachi et al., 2009). The differences in the community composition of tintinnid ciliates suggest that ciliated protozoan communities in the east and central Mediterranean are more diverse in terms of numbers of species, and species evenness (Dolan et al., 1999). It was proved (Elloumi et al., 2015) that class Spirotrichea was the most abundant ciliates at all the examined stations where they represented about $36.6 \%$ of the total abundance. The class of Spirotrich ciliates was followed by the oligohymenophoreans, with the highest percentage $(30 \%)$ of the total abundance recorded and then Heterotricheas are contributed to $10 \%$ and $50 \%$ of total abundance and biomass. Karyolectea and Colpodea were the least abundant classes; they did not exceed 10 $\%$ of the total ciliate abundance and biomass.

Simultaneously, Dorgham et al. (2013), emphasized that Bursaridium sp., Frontonia atra, Holophrya sp., Paramecium sp., Vasicola ciliata, and Vorticella sp. can be considered as indicators of eutrophication. Vorticella sp. stands out for its tolerance to a highly polluted environment exactly as proved by Salvado et al. (1995). In addition, $V$. ciliata was recorded in a stressed area at west of Alexandria coast (Abdel-Aziz, 2005).

The high abundance of ciliates indicated mostly that organic and nutrient materials might pollute the water bodies. However, neither species numbers nor abundance can be individually used for the bioassesment of water conditions. Number of species is sometimes not sensitive enough to reflect minor changes of water conditions. In addition, number of species may be more or less influenced by personal observations. On the other hand, sampling periods and intervals, geographical sites beside the tidal effects may reduce the statistical analysis consistency (Dolan and Coats, 1990; Park and Choi, 1997). A total of 8,000 described ciliate morphospecies include about 200 fossil tintinnids and 2,600 as commensals, leaving about 5,200 free-living species (Corliss, 2000). Regarding the relationships between the ciliated protozoan numerical densities and some of the physicochemical properties from the statistical point of view, it was proved that ciliates of the water samples are statistically significant in case of water temperature $(\mathrm{P}=0.026)$, dissolved oxygen $(\mathrm{P}=0.03)$ and total phosphates $(\mathrm{P}=0.03)$, while those of sand samples are significant with dissolved oxygen $(\mathrm{P}=0.05)$ and total phosphates only $(\mathrm{P}=0.02)$.

Making a comparison between data of the physico-chemical parameters of the present study with those of Emam et al. (2013), it was found that salinity levels achieved 32-39\%o in the first study, $33 \%$ For the second. The $\mathrm{p}^{\mathrm{H}}$ values proved to be slightly alkaline (7.6-7.98) at the previous studies, Those of dissolved oxygen were $(6.3-7.7)$ and $(6.9) \mathrm{mg} / \mathrm{L}$ respectively, while silicate concentrations were found to be $(0.02-0.06)$ and $(1.035) \mathrm{mg} / \mathrm{L}$ respectively. On the other hand, the nutritional levels of nitrates and phosphates for these two studies proved that nitrates are represented by $(0.06-0.096)$ and $(0.037) \mathrm{mg} / \mathrm{L}$, while those belonging to total phosphates are (0.02-0.08) and (0.08) $\mathrm{mg} / \mathrm{L}$, respectively.

The present study indicates that the average total ciliate densities were 4695, 2542 and 2220/L at western Alexandria, El-Hammam and Sedi A. Rhman respectively which means that ciliate numerical densities increased in the direction of east-west of the Mediterranean sea which is more or less similar with the results obtained by Pitta et al. (2001). At the same time, the higher numerical densities of ciliated protozoa of the sandy bottom samples, as compared with those of water samples belonging to those near-shore collections, could be referred to availability of the nutritive requirements and week currents in the former 


\section{Mansour A. Galal}

sampling stations. Variations in the present data could be attributed mostly to the illegal sewage discharge at the adjacent of Alexandria sampling station and/or due to predation influence of certain animals such as crustaceans, insect larvae and rotifers (Dolan et al., 1999 and Pitta et al., 2001). This conclusion is confirmed by data of the particulate organic carbon, total nitrates and phosphates. It was proved that ciliates of the water samples are statistically significant with water temperature $(\mathrm{P}=0.026)$, dissolved oxygen $(\mathrm{P}=0.03)$ and total phosphates $(\mathrm{P}=0.03)$, while those of sand samples are significant only with dissolved oxygen $(\mathrm{P}=0.05)$ and total phosphates only $(\mathrm{P}=0.02)$.

\section{REFERENCES}

Abdel-Aziz, N.E. (2004). The changes of zooplankton community in a chroniceutrophic bay on Alexandria coast, Egypt. Bull. Fac. Sci. Alex. Univ., 43 (1-2), 203-220.

Abdel-Aziz, N.E. (2005). Short term variations of zooplankton community in the West Naubaria Canal, Egypt, Egypt. J. Aquat. Res. (A.R.E.), 31 (1): 119-132.

Abdel-Aziz, N.E. and Aboul-Ezz, S.M. (2003). Zooplankton community of the Egyptian Mediterranean Coast, Egypt. J. Aquat. Biol. Fish., 7 (4): 91-108.

Anon, (2007). Final project report; distribution biological and rearing aspect of marine fish fries from Mediterranean Sea between Alexandria and Damietta. NIOS, Acad. Sci. Res., Alexandria.

APHA, American Public Health Association (2005). Standard methods for the examination of water and wastewater, American Public Health Association, $21^{\text {st }}$ ed, Academic Press, Washington D.C.

Balkis, N. (2004). Tintinnids (Protozoa: Ciliophora) of the Büyükcekmece Bay in the Sea of Marmara. Scientia Marina, 68 (1): 33-44.

Bel Hassen, M.; Drira, Z.; Hamza, A.; Ayadi, H.; Akrout, F. et al. ( 2008). Summer phytoplankton pigments and community composition related to water mass properties in the Gulf of Gabes. Estuarine, Coastal and Shelf Science, 77 (4): 645-656.

Cairns, J.Jt.; G.R. Lanza and B.C. Parker (1972). Pollution related to structural and functional changes in aquatic communities with emphasis on freshwater algae and protozoa. Proc. Acad. Nat. Sci. Philad., 124: 79 - 127.

Charubhun, B. and Charubhun, N. ( 2000). Biodiversity of freshwater Protozoa in Thailand, Kasetsart J. (Nat. Sci.), 34: 486-494.

Corliss, J.O. (1979). The ciliated protozoa: characterization, classification, and guide to the literature, Pergamon Press, Oxford, New York, 455 pp.

Corliss, J.O. (2000). Biodiversity, classification, and numbers of species of protists. In: Raven PH, Williams T(eds) Nature and human society. The quest for a sustainable world. National Academy Press, Washington, pp 130-155.

Corliss, J.O. (2002). Biodiversity and biocomplexity of the protists and an overview of their significant roles in maintenance of our biosphere. Acta Protozool, 41:199-219.

Corliss, J.O.; Cox, F.E.G.; Deroux, G.; Grain, J.; Hфnigberg, B.M.; Leedale, G.F.; Loeblich, A.R.; Lom,J.; Lynn,D.; Merinfeld, E.G.; Page, F.C.; Poljansky, G.; Sprague, V.; Vavra, J. and Wallace, F.G. (1980). A newly revised classification of the Protozoa. J. Protozool., 27: 37-58.

Dorgham, M.M.; Wael Salah El-Tohamy; Nagwa Elsayed Abdel Aziz; Ahmed El-Ghobashi and Jian, G. Qin, (2013). Protozoa in a stressed area of the Egyptian Mediterranean coast of Damietta, Egypt. Oceanologia, 55 (3): 733-750.

Dopheide, A.; Lear, G.; Stott R. and Lewis, G. (2009). Relative diversity community structure of ciliates in stream biofilms according to molecular and microscopy methods. Appl. Environ. Microb., 75 (16): 5261-5272. 


\section{Qualitative and quantitative evaluation of the ciliated protozoa in the middle northern coast of Egypt}

Dolan, J.R. and D.W. Coats (1990). Seasonal abundance of planktonic ciliates and microflagellates in mesohaline Chesapeake Bay waters. Estuar. Coast Shelf Sci., 31: 157 - 175.

Dolan, J.R.; Vidussi, F. and Claustre, H. (1999). Planktonic ciliates in the Mediterranean Sea, longitudinal trends. Deep-Sea Res. Pt. I, (46) 2025-2039.

Drira, Z.; Hamza, A.; Belhassen, M.; Ayadi, H.; Bouaïn, A. et al.,(2008). Dynamics of dinoflagellates and environmental factors during the summer in the Gulf of Gabes (Tunisia, Eastern Mediterranean Sea). Scientia Marina, 72 (1): 59-71.

Drira, Z.; Hamza, A.; Belhassen, M.; Ayadi, H.; Bouaïn, A. et al., (2010). Coupling of phytoplankton community structure to nutrients, ciliates and copepods in the Gulf of Gabès (south Ionian Sea, Tunisia). J. Mar. Biol. Assoc. U.K., 90 (6): 1203-1215.

El-Serehy, H.A.; Khaled, A. Al-Rasheid and Hesham Shafik (2012). Microbial Loop Populations: Their Abundances and Trophodynamics in the Gulf of Aqaba, Red Sea.

Turkish J. Fish. Aquat. Sci., 12: 565-573.

Elloump, J.; Drira, Z.; Guermazi, W.; Hamza, A. and Ayadi, H. (2015). Space-time variation of ciliates related to environmental factors in 15 nearshore of the Gulf of Gabes (Tunisia, Eastern Mediterranean Sea). Mediterranean Marine Science. Indexed in WoS (Web of Science, ISI Thomson) and SCOPUS. The journal is available on line at http://www.meditmar-sc.net .

Emam, W.M.; Saad, A.A.; , El-Moselhy, K.M. and Owen, N.A. (2013). Evaluation of water quality of Abu-Qir Bay, Mediterranean coast, Egypt. Intern. J. Environ. Sci. \& Eng. (IJESE), 4: 4754.

Fenchel, T. (1987). Ecology of Protozoa: the biology of free living phagotrophic protists. Science Tech Publisher, Madison, and Springer-Verlag, Berlin.

Finlay, B.J.; Esteban, G.F. and Fenchel, T. (2004) Protist diversity is different? Protist 155:15-22.

Foissner, W.; Chao, A. and Laura, A. Katz, L.A (2007). Diversity and geographic distribution of ciliates (Protista: Ciliophora). Biodivers Conserv. DOI 10.1007/s10531-007-9254-7.

Forge, T.A.; M.L. Berrow; J.F. Darbyshire and A.Warren. (1993). Protozoan bioassays of soil amended with sewage sludge and heavy metals, using the common soil ciliate Colpoda stenii. Biol. Fertil. Soils. 16: 282- 286.

Franco, C.; Esteban, G. and Téllez, C. (1998). Colonization and succession of ciliated protozoa associated with submerged leaves in a river. Limnologica, 28:275-283.

Galal, M. (1989). Ecological studies on the ciliate and bacterial populations of Slow sand filters. Ph.D Thesis, London University.

Hannachi, I.; Drira, Z.; Bel Hassen, M.; Hamza, A.; Ayadi, H. et al., (2009). Abundance and biomass of the ciliate community during a spring cruise in the Gulf of Gabes (East Mediterranean Sea, Tunisia). Acta protozoologica , 47: 293-305.

Ignatiades, L.; Karydis, M. and Vounatsou, P. (1992). A possible method evaluating oligotrophy and eutrophication based on nutrient concentrations, Mar. Pollut. Bull., 24 (5), 238.

Jiang, J. Wu S, Shen Y (2007) Effects of seasonal succession and water pollution on the protozoan community structure in an eutrophiclake. Chemosphere 66:523-532.

Jiang, Y., Xu, H., Hu, X., Zhu, M., Al-Rasheid,K.A.S. et al., ( 2011). An approach to analyzing spatial patterns of planktonic ciliate communities for monitoring water quality in Jiaozhou Bay, northern China. Mar. Pollut. Bull., 62 (2): 227-235.

Jiang, Y.; Xu, H.; Hu, X.; Warren, A. and Song, W. (2013). Functional groups of marine ciliated protozoa and their relationships to water quality. Environ. Sci. Pollut. Res., 20 (8): 52725280 .

Kneitel, J.M. and Chase J.M. (2004). Disturbance, predator, and resource interactions alter container community composition. Ecology, 85 (8): 2088-2093.

Lee, W.J. and J.K. Choi (2000). The role of heterotrophic protistis in the planktonic communities of Kyeonggi Bay, Korea.J.Kor.Soc.Oceanog.,35: 46 - 55.

Levine, N.D.; Corliss, J.O.; Cox, F.E.G.; Deroux, G.; Grain, J.; Hфnigberg, B.M.; Leedale, G.F.; Loeblich, A.R.; Lom, J.; Lynn, D.; Merinfeld, E.G.; Page, F.C.; Poljansky, G.; Sprague, V.; 


\section{Mansour A. Galal}

Vavra, J. and Wallace, F.G. (1980). A newly revised classification of the Protozoa. J. Protozool., 27: 37-58.

Madoni, P. and Braghiroli, S. (2007).Changes in the ciliate assemblage along a fluvial system related to physical, chemical and geomorphological characteristics. Europ.J. Protistol., 43 (2): 67 75.

Marchetti, R.(1984). Quadro analitico complessivo del risultati delle indagini condotte negli anni 1977-1980. II. Problema dell'eutrofizzazione delle acque costiere dell'Emilia Romagna: situazione ipotesi di intervento, Regione Emilia Romagna, Bologna, 308 pp.

Park, G.S. and Choi, J. K. (1997). Microzooplankton assemblages; their distribution , trophic rate and relationship to the environmental variables. J. Kor. Soc. Oceanogr., 32: $145-155$.

Pitta, P.; Giannakourou, A. and Christaki, U. (2001). Planktonic ciliates in the oligotrophic Mediterranean Sea: longitudinal trends of standing stocks, distributions and analysis of food vacuole contents, Aquat. Microb. Ecol., 24, 297-311.

Salvado, H.; Gracia, M.P. and Amigo, J.M., (1995). Capability of ciliated protozoa as indicators of effluent quality in activated-sludge plants. Water Res., 29 (4):1041-1050.

Sime-Ngando, T.; Gosselin, M.; Roy, S. and Chanut, J.P. (1995). Significance of planktonic ciliated protozoa in the lower St. Lawrence estuary: comparison with bacterial, hytoplankton, and particulate organic carbon. Aquat Microb. Ecol., 9:243-258.

Siokou-Frangou, I.; Christak, U.; Mazzocchi, M.G.; Montresor, M.; M. Ribera, M.; Vaqu, D. and Zingone, A. (2010). Plankton in the open Mediterranean Sea: a review. Biogeosciences, 7 : $1543-1586$.

Utermohl, E. (1958). In Vollenweider R.A. (1974). A manual of method for measuring primary production in aquatic environments. IBP Handbook no. 12 London, Blackwell, p.8.

Vickerman, K.(1992). Diversity and ecological significance of protozoa Biodivers. Conserv., 1 (4): 334-341.

Vucak, Z.A.S. and Stirn, J. (1982). Basic physical, chemical and biological data reports, .V.A Mohorov ICIC Adriatic cruises 1974-76. Hydrogr. Inst. Yugoslav Navy, Split, 175 pp.

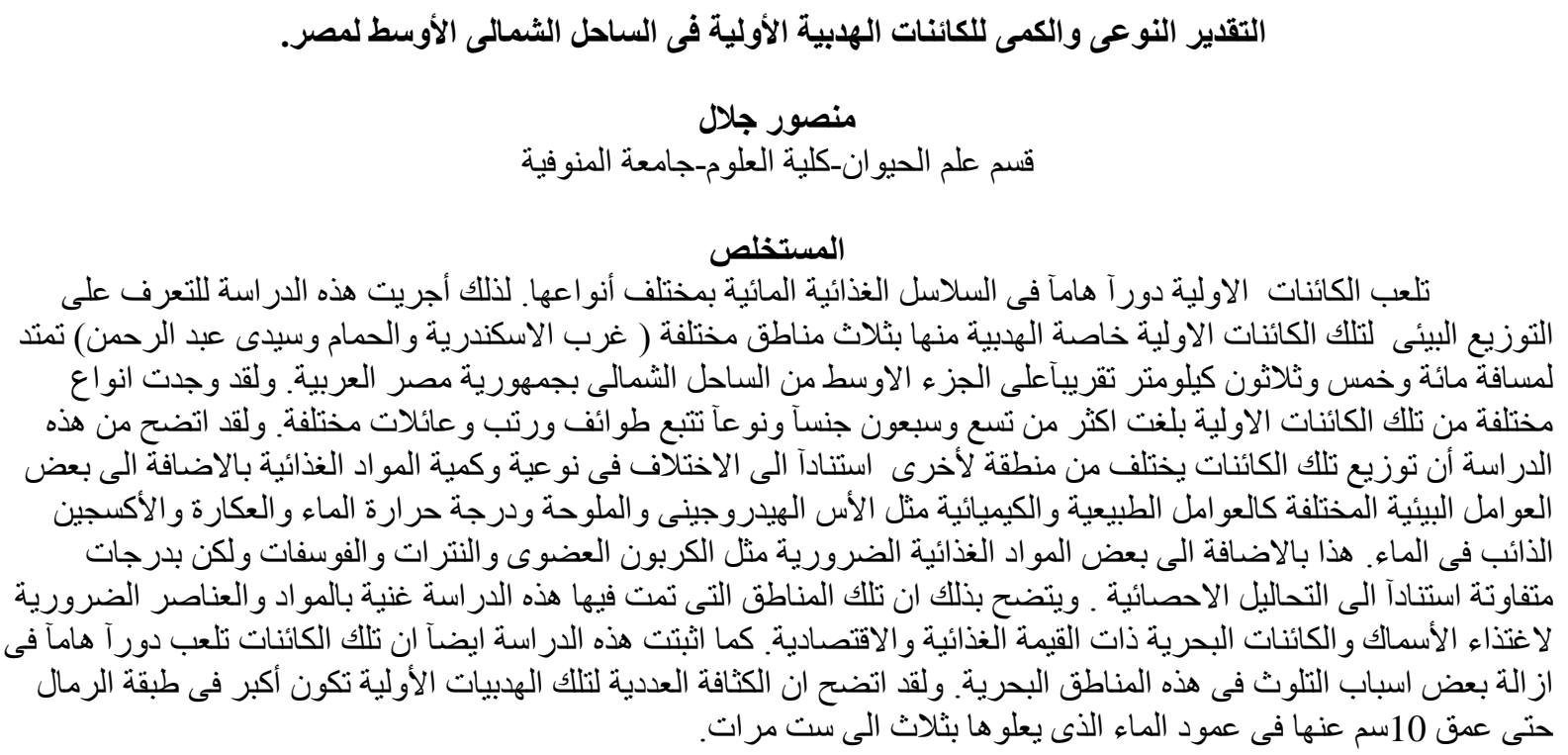

